\title{
ADAPTASI DIRI PADA LANSIA DI PANTI WERDHA MOJOPAHIT MOJOKERTO
}

\author{
Dwi Harini Puspitaningsih ${ }^{\mathbf{1}}$, Duduk Adi Prasetyo ${ }^{2}$ ) \\ ${ }^{1}$ Dosen Politeknik Kesehatan Majapahit \\ ${ }^{2}$ Mahasiswa Politeknik Kesehatan Majapahit
}

\begin{abstract}
The fact that happens in Panti Werdha Mojopahit Mojokerto is the social problems, such as many people who live inside are often alone and rarely out with their friend and also they look uncomfortable living in panti werdha because they can't adjust their selves in their environment of panti. The purpose of this study is to know the overview of self adaptation to elderly in Panti Werdha Mojopahit Mojokerto. Design of this study is descriptive with survey. The variabel of this study is self adaptation to elderly. The population of this study is all of elderly in Panti Werdha Mojopahit Mojokerto amount 37 elderly. The sampling taken with technique of total sampling amount 37 respondents. Data collected with questionnaire and processed by coding, editing, scoring and tabulating and presented in from of a frequency distribution table. Results of the study showed that most respondents have a negative self adaptation amount 22 respondents $(59,5 \%)$ and a positive self adaptation amount 15 respondents (40.5\%). The result analysis of overview self adaptation to elderly in Panti Werdha Mojopahit Mojokerto using a likert scale changed to score T. it will be positive the result of if score $T$ is $\geq 50$ and it will be negative if the result of score $T$ is $<50$. The results of this study showed that the elderly who live in panti werha have the pressure from the internal environment and make uncomfortable between elderly inside and quarrel between them. So many elderly who haven't yet adjust their personality and sosical adaptation are more increased the environment in Panti Werdha Mojopahit. Coaching and councelling are more increased make the elderly to undergo their life and be able to adapt well.
\end{abstract}

Keywords : Self Adaptation, Elderly

\section{A. PENDAHULUAN}

Adanya perubahan fisiologi dan psikologis pada lansia, membuat keluarga menempatkan lansia di panti werdha, dengan alasan kurang mampu merawat lansia dengan baik. Jika lansia tinggal di panti werdha, maka mereka akan mengalami suatu perubahan di dalam hidupnya. Yang paling menonjol adalah perubahan sosial. Disana mereka akan bertemu dengan teman sebayanya yang memiliki sifat dan karakter yang berbeda. Untuk itu, lansia tersebut harus beradaptasi atau menyesuaikan diri dengan kelompok sosialnya (Prasetyo, 2013). Kenyataan yang terjadi di Panti Werdha Mojopahit Mojokerto terdapat permasalahan sosial seperti mereka sering menyendiri jarang bergaul dengan teman-temannya dan mereka kelihatan tidak nyaman tinggal di panti karena mereka belum mampu menyesuaikan diri dengan keadaan di lingkungan panti. Akan tetapi masih terdapat lansia yang juga merasa nyaman untuk tetap tinggal di Panti Werdha dan mereka tidak ingin untuk tinggal di luar Panti meskipun keluarga berusaha untuk tetap menjenguk dan mengajak mereka untuk pulang akan tetapi lansia tidak ingin pulang. Dan untuk mengisi waktu lansia berusaha untuk mengisi kesibukan dengan membuat karya seperti melukis atau memuat hasil karya yang lain.

Sejauh ini prevalensi depresi di dunia berkisar 8,15\%. Depresi bukanlah hal yang normal terjadi pada lansia walaupun depresi biasa terjadi pada lansia. Kira-kira 3 dari 100 
orang lansia berusia diatas 65 tahun mengalami depresi (Keliat, Akemat, Helena, et.al, 2011). Berdasarkan data BKKBN tahun 2011 jumlah penduduk dunia telah mencapai angka 7 miliar jiwa dan 1 miliar di antaranya adalah penduduk lanjut usia (lansia). Indonesia sendiri menduduki rangking keempat di dunia dengan jumlah lansia 24 juta jiwa yang belum terlalu mendapat perhatian. Sensus penduduk tahun 2010 menunjukkan bahwa penduduk lansia usia 60 tahun ke atas meningkat secara signifikan. Kalau pada tahun 1960-an dan 1970-an penduduk lansia mungkin hanya sekitar 2 persen, saat ini sudah menjadi sekitar 10 persen dari 238 juta jiwa (Aby, 2011).

Hasil studi pendahuluan yang dilakukan pda tanggal 03-05 Maret 2014 di Panti Werdha Mojopahit Mojokerto dengan menggunakan kuesioner terhadap 10 lansia diperoleh data 6 lansia (60\%) menyatakan bahwa masih belum mampu menjaga dan melakukan perawatan diri dengan baik, merasa tidak nyaman dengan keadaan yang dialami sekarang dan meraka masih belum mampu untuk bergaul dengan temantemannya secara rutin, kebanyakan responden lebih banyak berdiam diri, dan mereka merasa belum puas dengan kondisi yang dialami saat ini seperti hidup sendiri, melakukan kegiatan secara mandiri, dan terkadang harus tergantung pada petugas dalam melakukan kegiatan yang tidak mampu dilakukan secara mandiri dimana mereka masih merasa tidak enak ketika meminta bantuan tersebut, sedangkan 4 lansia (40\%) menyatakan bahwa mereka sudah cukup merasa puas dengan keadaannya di panti, mereka mempunyai keinginan untuk berkumpul dengan teman-temannya lebih akrab dan mereka selalu berusaha untuk mengerjakan segala sesuatu secara mandiri meskipun bantuan dari petugas panti selalu ditawarkan pada lansia, dan juga mereka selalu berusaha untuk dapat menolong teman-temannya jika mengalami kesulitan serta berusaha untuk dapat menghibur teman-temannya semua.

Upaya yang dapat dilakukan sebagai tenaga kesehatan antara lain pemberian perhatian dan penjelasan pada lansia tentang perubahan yang terjadi sehingga lansia akan lebih memahami dan mengerti tentang keadaannya saat ini dan dapat mengurangi depresi yang terjadi. Disamping itu diharapkan pada lansia untuk dapat melakukan aktivitas olahraga setiap hari atau 2 hari sekali untuk dapat melakukan relaksasi dan menghilangkan kejenuhan. Dukungan dari keluarga juga sangat dibutuhkan bagi para lansia dimana diharapkan keluarga dapat menjenguk lansia yang berada di panti meskipun tidak setiap hari, dimana keadaan tersebut dapat menimbulkan perasaan masih dihargai pada lansia sehingga mereka dapat merasa lebih nyaman tinggal di Panti. Sehubungan dengan hal tersebut maka penulis tertarik untuk melakukan penelitian yang berjudul "gambaran adaptasi diri lansia di Panti Werdha Mojopahit Mojokerto.".

\section{B. TINJAUAN PUSTAKA}

\section{Konsep Dasar Adaptasi}

\section{a. Pengertian Adaptasi}

Adaptasi adalah proses dimana dimensi fisiologis dan psikososial berubah dalam berespon terhadap stress. Karena banyak stressor tidak dapat dihindari, promosi kesehatan sering difokuskan pada adaptasi individu, keluarga atau komunitas terhadap stress. Ada banyak bentuk adaptasi. Adaptasi fisiologis memungkinkan homeostasis fisiologis. Namun demikian mungkin terjadi proses yang serupa dalam dimensi psikososial dan dimensi lainnya (Ardi, 2013).

\section{b. Elemen Adaptasi}

Roy dengan fokus adaptasinya pada manusia terdapat 4 elemen esensial yaitu keperawatan, manusia, kesehatan dan lingkungan.

c. Jenis Adaptasi Lansia

Jenis adaptasi pada lansia menurut Sinta (2013) yaitu : 
1) Penyesuaian Terhadap Karier (Pekerjaan)

Penelitian tentang pekerja lanjut usia menekankan pada kualitas kerja yang menyumbang keberhasilan mereka dalam kerja. Pekerja lanjut usia, misalnya karena mereka banyak memiliki pengalaman, cenderung bekerja dengan gerak yang lamban daripada pekerja muda yang kurang berpengalaman.

2) Penyesuaian Diri Dalam Kehidupan Sosial

Lansia memiliki status kelompok minoritas karena sebagai akibat dari sikap sosial yang tidak menyenangkan terhadap orang lanjut usia dan diperkuat oleh pendapat-pendapat klise yang jelek terhadap lansia. Perubahan peran pada lansia sebaiknya dilakukan atas dasar keinginan sendiri bukan atas dasar tekanan dari lingkungan. Aktivitas sosial yang banyak pada lansia juga mempengaruhi baik buruknya kondisi fisik dan sosial lansia. (Santrock, 2009).

3) Penyesuaian Diri Terhadap Keluarga

Sebagian besar hubungan lansia dengan anak jauh kurang memuaskan yang disebabkan oleh berbagai macam hal. Penyebabnya antara lain : kurangnya rasa memiliki kewajiban terhadap orang tua, jauhnya jarak tempat tinggal antara anak dan orang tua. Lansia tidak akan merasa terasing jika antara lansia dengan anak memiliki hubungan yang memuaskan sampai lansia tersebut berusia 50 sampai 55 tahun. Orang tua usia lanjut yang perkawinannya bahagia dan tertarik pada dirinya sendiri maka secara emosional lansia tersebut kurang tergantung pada anaknya dan sebaliknya. Umumnya ketergantungan lansia pada anak dalam hal keuangan. Karena lansia sudah tidak memiliki kemampuan untuk dapat memenuhi kebutuhan hidupnya. Anak-anaknya pun tidak semua dapat menerima permintaan atau tanggung jawab yang harus mereka penuhi. Perubahan-perubahan tersebut pada umumnya mengarah pada kemunduruan kesehatan fisik dan psikis yang akhirnya akan berpengaruh juga pada aktivitas ekonomi dan sosial mereka. Sehingga secara umum akan berpengaruh pada aktivitas kehidupan seharihari.

\section{d. Aspek-aspek adaptasi diri pada lansia}

Adaptasi diri seorang lansia yang sukses apabila lansia merasakan kebahagiaan, oleh sebab itu perlunya penyesuaian diri lansia terhadap masa pensiun. Menurut Juliana (2006) penyesuaian diri memiliki dua aspek yaitu :

1) Adaptasi Pribadi

Keberhasilan penyesuaian pribadi ditandai dengan tidak adanya rasa benci, lari dari kenyataan dan tanggung jawab, dongkol, kecewa, atau tidak percaya pada kondisi yang dialaminya, sebaliknya, kegagalan dalam penyesuaian pribadi ditandai dengan guncangan emosi, kecemasan, ketidakpuasan antara individu dengan tuntutan lingkungan.

2) Adaptasi Sosial

Di dalam masyarakat terjadi proses saling mempengaruhi antar setiap individu. Dari proses tersebut timbul suatu pola kebudayaan dan tingkah laku sesuai dengan sejumlah aturan, hukum, adat, dan nilai-nilai yang mereka patuhi demi untuk mencapai penyesuaian bagi persoalan hidup seharihari. Dalam bidang ilmu psikologi sosial, proses ini dikenal dengan proses penyesuaian sosial, proses ini dikenal dengan proses penyesuaian sosial. Penyesuaian sosial terjadi dalam lingkup hubungan sosial tempat individu hidup dan berinteraksi dengan orang lain. Hubungan-hubungan tersebut 
mencakup hubungan dengan masyarakat di sekitar tempat tinggalnya keluarga, sekolah, teman, atau masyarakat secara umum. Dalam hal ini individu dan masyarakat sama-sama memberikan dampak bagi komunitas individu menyerap berbagai informasi, budaya, adat istiadat yang ada. Sementara komunitas diperkaya oleh eksistensi atau karya yang diberikan oleh individu sendiri.

\section{Konsep Lansia}

\section{a. Pengertian Usia Lanjut}

Menurut Constantinides yang dikutip oleh Maryam (2008) penuaan adalah suatu proses menghilangnya secara perlahan kemampuan jaringan untuk memperbaiki diri atau mengganti diri atau mempertahankan struktur serta fungsi normalnya sehingga tidak dapat bertahan terhadap jejas (termasuk infeksi) dan memperbaiki kerusakan yang diderita.

Menurut Prof Dr. R. Boedhi Darmojo dan Dr. Hadi Martono daam Nugroho (2008) proses menua adalah suatu proses menghilangnya secara perlahan kemampuan jaringan untuk memperbaiki dirir atau mengganti diri dan mempertahankan struktur dan fungsi normalnya sehingga tidak dapat bertahan terhadap jejas (termasuk infeksi) dan memperbaiki kerusakan yang diderita.

\section{b. Teori-Teori Proses Menua}

Terdapat beberapa teori tentang proses penuaan menurut Pujiastuti (2003), yaitu :

1) Teori Genetik

a) Teori Hayflick. Menurut studi Hayflick dan Moorehead (1961), penuaan disebabkan oleh berbagai faktor, antara lain perubahan fungsi sel, efek kumulatif dari tidak normalnya sel, dan kemunduran sel dalam organ dan jaringan.

b) Teori kesalahan. Dalam teori ini dinyatakan bahwa kesalahan dalam proses atau mekanisme pembuatan protein akan mengakibatkan beberapa efek. Penurunan ketepatan sintesis protein secara spesifik telah dihipotesiskan penyebabnya, yaitu ketidaktepatan dalam penyiapan pasangan kodon mRNA dan antikodon tRNA.

c) Teori DNA lewah (kelebihan DNA). Medvedev (1972) mengemukakan teori yang berhubungan dengan teori kesalahan. Ia percaya bahwa perubahan usia biologis merupakan hasil akumulasi kesalahan dalam memfungsikan gen (plasma pembawa sifat).

d) Teori Rekaman (transcription) adalah tahap awal dalam pemindahan informasi dari DNA ke sintesis protein.

2) Teori Nongenetik

a) Teori Radikal Bebas

Pada dasarnya radikal bebas adalah ion bermuatan listrik yang berada di luar orbit dan berisi ion tak berpasangan. Radikal bebas mampu merusak membran sel, lisosom, mitokondria, dan inti membran melalui reaksi kimia yang disebut peroksidase lemak. Perubahan hormon pada penuaan menunjang reaksi radikal bebas dan akan menimbulkan efek patologis, seperti kanker, aterosklerosis.

b) Teori autoimun

Menurut teori auto imun, penuaan diakibatkan oleh antibodi yang bereaksi terhadap sel normal dan merusaknya. Reaksi itu terjadi karena tubuh gagal mengenal sel normal dan memproduksi antibodi yang salah. 
Akibatnya, antibodi itu bereaksi terhadap sel normal, di samping sel abnormal yang menstimulasi pembentukannya.

c) Teori Hormonal

Hipotiroidisme dapat menjadi fatal apabila tidak diobati dengan tiroksin, sebab seluruh manifestasi dari penuaan akan tampak, seperti penurunan sistem kekebalan, kulit keriput, uban, dan penurunan proses metabolisme secara perlahan.

d) Teori Pembatasan energi

Diet nutrisi tinggi rendah kalori berguna untuk meningkatkan fungsi tubuh agar tidak cepat tua. Program pembebasan energi bertujuan untuk mengurangi berat badan secara bertahap dalam beberapa tahun sampai efisiensi metabolisme tercapai untuk hidup sehat dan panjang usia.

\section{c. Batasan Lansia}

Terdapat beberapa pendapat mengenai batasan-batasan umur lansia.:

1) Menurut Maryam (2010) usia Lanjut usia meliputi :

a) Pra Usia Lanjut (Prasenilis)

Seseorang yang berusia antara 45 - 59 tahun

b) Usia Lanjut

Seseorang yang berusia 60 tahun atau lebih. Usia lanjut adalah tahap masa tua dalam perkembangan individu (usia 60 tahun ke atas)

c) Usia Lanjut Usia Resiko Tinggi

Seseorang yang berusia 70 tahun atau lebih atau seseorang yang berusia 50 tahun atau lebih dengan masalah kesehatan

d) Usia lanjut potensial

Usia lanjut yang mampu melakukan pekerjaan dan atau kegiatan yang dapat menghasilkan barang atau jasa

e) Usia lanjut tidak potensial

Usia lanjut yang tidak berdaya mencari nafkah sehingga hidupnya bergantung pada bantuan orang lain.

2) Menurut Prof. Dr. Ny. Sumiati Ahmad Muhammad (Nugroho,2008). Membagi periodisasi biologi perkembangan manusia sebagai berikut :
a) 0-1 tahun : masa bayi
b) 1-6 tahun : masa prasekolah
c) 6-10 tahun : masa sekolah
d) 10-20 tahun : masa pubertas
e) 40-65 tahun : masa setengah umur (prasenium)
f) 65 tahun keatas : masa lanjut usia (senium)

\section{d. Faktor-Faktor Yang Mempengaruhi Penuaan}

Menurut Pudjiastuti (2003), faktor yang mempengaruhi penuaan antara lain:

1) Faktor endogen : perubahan sel-sel tubuh

2) Faktor Eksogen : Lingkungan, Sosial Budaya, Gaya hidup

\section{e. Perubahan Yang Terjadi Pada Lanjut Usia}

Menurut Nugroho (2008) perubahan yang terjadi pada lansia adalah:

1) Perubahan fisik

2) Sistem persyarafan, Cepatnya menurun hubungan persyarafan

3) Sistem pendengaran. Sistem penglihatan

Sfingter pupil timbul sclerosis dan hilangnya respon terhadap sinar.

4) Sistem kardiovaskular

5) Sistem respirasi 
6) Sistem gastrointestinal. Kehilangan gigi, Indra pengecap menurun, Esofagus melebar, Lambung, Peristaltik lemah dan biasanya timbul konstipasi., Fungsi absorsi melemah (daya absorpsi terganggu). Liver (hati):

7) Sistem genitourinaria: Ginjal, Vesika urinaria/ kandung kemih, Pembesaran prostate $\pm 75 \%$ dialami oleh pria usia 65 tahun, Atrofivulfa, Vagina, Daya seksual. Sistem endrokin.

8) Sistem kulit: Kulit mengkerut atau keriput akibat kehilangan jaringan lemak., Kulit kepala dan rambut menipis berwarna kelabu, Rambut dalam hidung dan telinga menebal, Berkurangnya elastisitas akibat dari menurunnya cairan dan vaskularisasi, Kuku jari menjadi keras dan rapuh, Kuku kaki tumbuh secara berlebihan dan seperti tanduk.

9) Sistem musculoskeletal

10) Perubahan-perubahan mental

\section{Konsep Panti Werdha}

\section{a. Tujuan dan Fungsi Pelayanan Panti Wreda}

Tujuan pedoman pelayanan ini adalah memberi arah dan memudahkan petugas dalam memberikan pelayanan sosial, kesehatan dan perawatan lanjut usia di PSTW (Panti Sosial Tresna Werdha), serta meningkatkan mutu pelayanan bagi lanjut usia.

\section{b. Fungsi Pelayanan Panti Wreda}

Fungsi pelayanan dapat berupa pusat pelayanan sosial lanjut usia, pusat informasi pelayanan sosial lanjut usia, pusat pengembangan pelayanan sosial lanjut usia, dan pusat pemberdayaan lanjut usia.

Sasaran pelayanan ini adalah lanjut usia potensial, yaitu lanjut usia yang berusia 60 tahhun ke atas, masih mampu melakukan pekerjaan atau kegiatan yang dapat menghasilkan barang dan jasa. Lanjut usia tidak potensial adalah lanjut usia yang berusia 60 tahun ke atas, tidak berdaya mencari nafkah sehingga hidupnya bergantung pada bantuan orang lain, keluarga lanjut usia, masyarakat, kelompok, dan organisasi social

\section{c. Kebutuhan Lansia}

1) Kebutuhan Biologis: Makan dan minum, Pakaian, Tempat tinggal, Olahraga, Istirahat/tidur

2) Kebutuhan Psikologis: Sering marah, Rasa aman dan tenang, Ketergantungan, Sedih dan kecewa, Kesepian

3) Kebutuhan Sosial: Aktifitas yang bermanfaat, Kesulitan menyesuaikan diri. Kesulitan berhubungan dengan orang lain. Bersosialisasi dengan sesama lansia. Kunjungan keluarga. Rekreasi/hiburan (di dalam dan di luar panti). Tabungan/simpanan bagi lansia yang berpenghasilan

4) Kebutuhan Spiritual: Bimbingan kerohanian, Akhir hayat yang bermartabat.

\section{METODE PENELITIAN}

\section{Jenis Dan Rancang Bangun Penelitian}

Jenis Penelitian ini adalah deskriptif merupakan penelitian yang hanya untuk menggambarkan atau mendeskripsikan variabel tertentu dalam suatu penelitian tanpa mencari hubungan antar variabel (Saryono, 2010). Penelitian ini mendiskripsikan adaptasi diri pada lansia dan pendekatan ini menggunakan pendekatan metode survey yang dilakukan dengan menyebarkan kuesioner atau wawancara, dengan tujuan untuk mengetahui, menerangkan atau menjelaskan : siapa mereka, apa yang mereka pikir, rasakan, atau kecenderungan suatu tindakan (Prasetyono,2011). 


\section{Kerangka Konseptual.}

Faktor yang mempengaruhi adaptasi lansia :

1. Persiapan hari tua

2. Pengalaman masa lalu

3. Kepuasan dari kebutuhan

4. Kenangan

5. Anak-anak yang telah dewasa

6. Sikap sosial

7. Sikap pribadi

8. Metode penyesuaian diri

9. Kondisi penyakit

10. Kondisi hidup
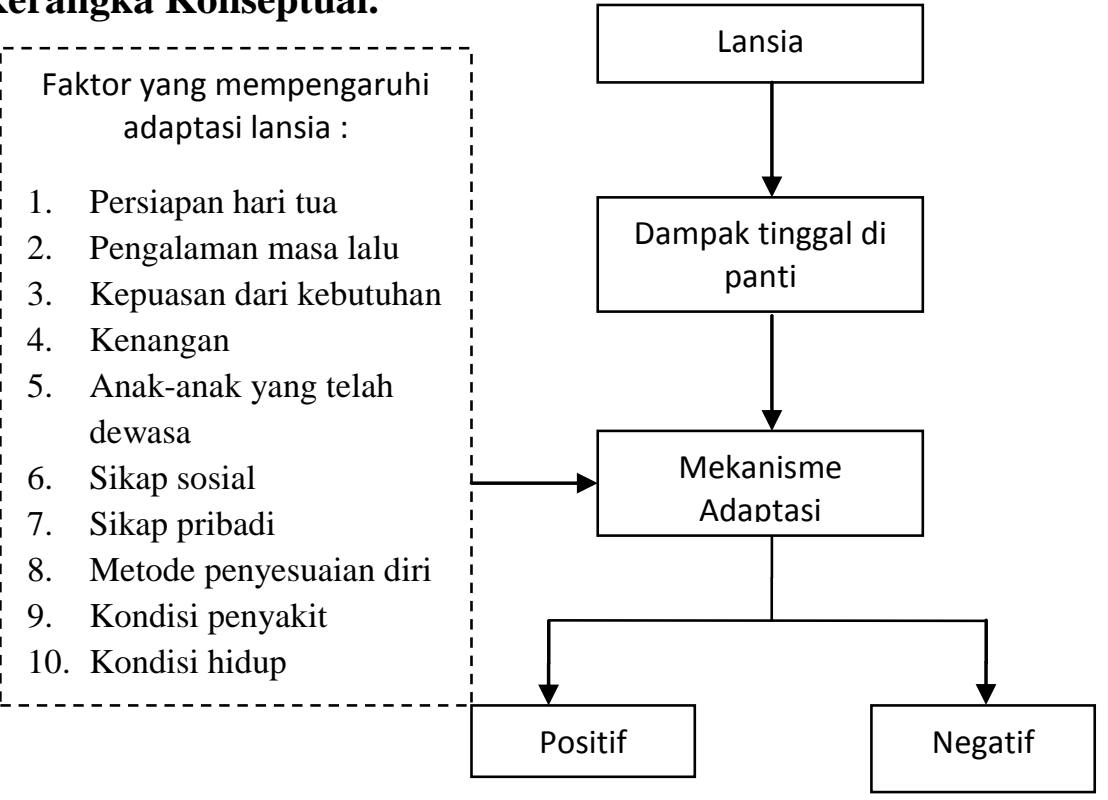

Keterangan :

\section{: Diteliti}

: Tidak diteliti

Gambar 1 Kerangka Konseptual gambaran adaptasi diri lansia di Panti Werdha Mojopahit Mojokerto.

\section{Populasi dan Sampel}

Populasi penelitian ini adalah seluruh Lansia di Panti Werdha Mojopahit Mojokerto sebanyak 37 lansia. Dalam penelitian ini, peneliti menggunakan teknik total sampling, pemilihan sampel ini dikarenakan semua populasi mudah untuk ditemui dan peneliti memiliki cukup waktu untuk melakukan penelitian

\section{Variabel, Definisi Operasional}

\section{Jenis Variabel}

Variabel menandung pengertian ukuran, sifat atau ciri yang di miliki oleh anggota-anggota kelompok yang berbeda dengan yang dimiliki oleh kelompok lain (Notoadmodjo, 2010). Variabel dalam penelitian ini yaitu adaptasi diri pada lansia.

2. Definisi operasional variabel

Tabel 1 Definisi Operasional Adaptasi diri pada lansia di Panti Werdha Mojopahit Mojokerto

\begin{tabular}{|c|c|c|c|}
\hline Variabel & Definisi Operasional & Kriteria & Skala \\
\hline $\begin{array}{l}\text { Adaptasi } \\
\text { diri pada } \\
\text { lansia di } \\
\text { Panti } \\
\text { Werdha } \\
\text { Mojopahit } \\
\text { Mojokerto }\end{array}$ & $\begin{array}{l}\text { Suatu kondisi yang dilakukan } \\
\text { oleh lansia di Panti Werdha } \\
\text { Mojopahit Mojokerto dalam } \\
\text { menyesuaikan dengan kondisi } \\
\text { dan situasi lingkungan } \\
\text { disekitarnya } \\
\text { yang diukur dengan } \\
\text { menggunakan indikator: } \\
\text { 1. Adaptasi Pribadi } \\
\text { 2. Adaptasi Sosial } \\
\text { Yang diukur dengan } \\
\text { menggunakan kuesioner }\end{array}$ & $\begin{array}{l}\text { 1. Positif Jika } \\
\text { skor } \mathrm{T} \geq 50 \\
\text { 2. Negatif Jika } \\
\text { skor } \mathrm{T}<50 \\
\text { Azwar }(2011)\end{array}$ & Nominal \\
\hline
\end{tabular}




\section{Teknik dan Instrumen Pengumpulan Data}

Langkah-langkah dalam pengumpulan data penelitian dilakukan mulai dari pengurusan surat dari pemerintah Kabupaten Mojokerto kemudian surat diajukan pada Dinas Sosial Kabupaten Mojokerto dan Panti Werdha Mojopahit Mojokerto. Setelah itu peneliti melakukan pendekatan kepada responden sambil menjelaskan maksud dan tujuan penelitian sehingga responden bersedia untuk diteliti dan dimohon untuk menandatangani pernyataan menjadi responden. Setelah responden bersedia peneliti melakukan teknik wawancara pada responden kemudian dilakukan proses analisa data mulai dari editing, coding, scoring, dan tabulating

6. Teknik Pengumpulan Data

Pada penelitian ini kuesioner dengan jenis pertanyaan tertutup yang digunakan untuk mengukur adaptasi diri pada lansia. Kuesioner yang digunakan pada penelitian ini menggunakan kuesioner yang telah digunakan oleh Gustyana Indrasmitha pada tahun 2009

\section{HASIL PENELITIAN}

1. Data Umum

1) Karakteristik Responden Berdasarkan Umur

Berdasarkan hasil penelitian yang sudah dilakukan didapatkan karakteristik responden berdasarkan umur responden sebagai berikut

Tabel 2 Distribusi Frekuensi Responden Berdasarkan Umur di Panti werdha Mojopahit Mojoketo Tanggal 13 - 17 Mei 2014

\begin{tabular}{|l|c|c|}
\hline \multicolumn{1}{|c|}{ Usia Responden } & Frekuensi & Persen \\
\hline $60-65$ tahun & 1 & 2.7 \\
\hline $66-70$ tahun & 13 & 35.1 \\
\hline$>70$ tahun & 23 & 62.2 \\
\hline Total & 37 & 100 \\
\hline
\end{tabular}

Tabel Menunjukkan bahwa sebagian besar usia responden adalah usia $>70$ tahun sebanyak 23 responden $(62,2 \%)$.

2) Karakteristik Responden Berdasarkan Pendidikan

Berdasarkan hasil penelitian yang sudah dilakukan didapatkan karakteristik responden berdasarkan pendidikan sebagai berikut :

Tabel 3 Distribusi frekuensi Responden Berdasarkan Pendidikan di Panti werdha Mojopahit Mojoketo Tanggal 13-17 Mei Tahun 2014

\begin{tabular}{|l|c|c|}
\hline \multicolumn{1}{|c|}{ Pendidikan } & Frekuensi & Persen \\
\hline Dasar (SD, SLTP) & 37 & 100 \\
\hline Menengah (SLTA) & 0 & 0 \\
\hline Tinggi (D3, S1) & 0 & 0 \\
\hline Total & 37 & 100 \\
\hline
\end{tabular}

Tabel diatas diperoleh data bahwa seluruh responden mempunyai latar belakang pendidikan dasar (SD dan SMP) yaitu sebanyak 37 responden (100\%). 
3) Karakteristik Responden Berdasarkan Pensiunan

Berdasarkan hasil penelitian yang sudah dilakukan didapatkan karakteristik responden berdasarkan pensiunan sebagai berikut :

Tabel 4 Distribusi frekuensi Responden Berdasarkan riwayat pensiunan di Panti werdha Mojopahit Mojoketo Tanggal 13-17 Mei Tahun 2014

\begin{tabular}{|l|c|c|}
\hline \multicolumn{1}{|c|}{ Pensiunan } & Frekuensi & Persen \\
\hline Ya & 1 & 2,7 \\
\hline Tidak & 36 & 97,3 \\
\hline Total & 37 & 100 \\
\hline
\end{tabular}

Tabel diatas diperoleh data bahwa hampir seluruhnya responden tidak mempunyai pensiunan sebanyak 36 responden $(97,3 \%)$.

4) Karakteristik Responden Berdasarkan Alasan Tinggal Di Panti

Berdasarkan hasil penelitian yang sudah dilakukan didapatkan karakteristik responden berdasarkan Alasan tinggal di panti sebagai berikut :

Tabel 5 Distribusi frekuensi Responden Berdasarkan alasan tinggal di Panti werdha Mojopahit Mojoketo Tanggal 13-17 Mei Tahun 2014

\begin{tabular}{|l|l|l|}
\hline \multicolumn{1}{|c|}{ Alasan Tinggal Di Panti } & Frekuensi & \multicolumn{1}{c|}{ Persen } \\
\hline Sendiri & 23 & 62,2 \\
\hline Keluarga & 14 & 37,8 \\
\hline Total & 37 & 100 \\
\hline
\end{tabular}

Tabel diatas diperoleh data bahwa sebagian besar responden tingal di Panti

Werdha Mojopahit karena keinginan sendiri sebanyak 23 responden $(62,2 \%)$.

\section{Data Khusus}

Berdasarkan hasil penelitian yang sudah dilakukan didapatkan karakteristik responden berdasarkan adaptasi diri lansia sebagai berikut :

Tabel 6 Distribusi frekuensi Responden Berdasarkan adaptasi diri lansia di Panti werdha Mojopahit Mojoketo Tanggal 13-17 Mei Tahun 2014

\begin{tabular}{|c|c|c|}
\hline Adaptasi Diri Lansia & Frequency & Percent \\
\hline Positif & 15 & 40,5 \\
\hline Negatif & 22 & 59,5 \\
\hline Total & 37 & 100 \\
\hline
\end{tabular}

Tabel menunjukkan bahwa sebagian besar responden mempunyai adaptasi diri yang negatif sebanyak 22 responden $(59,5 \%)$.

\section{E. PEMBAHASAN}

Hasil penelitian yang dilakukan Tanggal 13 - 17 Mei tahun 2014 di Panti Werdha Mojopahit Mojokerto terhadap 37 responden didapatkan hasil bahwa sebagian besar responden mempunyai adaptasi diri yang negatif sebanyak 22 responden $(59,5 \%)$. Berdasarkan parameter adaptasi pirbadi diperoleh data yaitu sebagian besar responden mempunyai adaptasi pribadi yang negatif sebanyak 20 responden $(54,1 \%)$, sedangkan berdasarkan parameter adaptasi sosial diperoleh data yaitu sebagian besar responden mempunyai adaptasi sosial yang negatif sebanyak 21 responden $(56,8 \%)$.

Menurut Prof Dr. R. Boedhi Darmojo dan Dr. Hadi Martono daam Nugroho (2008) proses menua adalah suatu proses menghilangnya secara perlahan kemampuan jaringan untuk memperbaiki diri atau mengganti diri dan mempertahankan struktur dan fungsi normalnya sehingga tidak dapat bertahan terhadap jejas (termasuk infeksi) dan memperbaiki kerusakan yang diderita. Sedangkan kecemasan adalah perasaan tidak tenang (ketakutan) yang dialami oleh individu atau kelompok dan aktivitas sistem saraf otonom dalam merespon yang tidak spesifik dan tidak jelas (Carpenito, 2009). 
Hasil penelitian ini menunjukkan bahwa lansia yang tinggal di panti werdha mempunyai tekanan dari lingkungan internal dan eksternal, dimana tekanan tersebut lebih kepada hubungan antara penghuni (teman-temannya) yang tidak cocok dalam bergaul antara satu dengan lainnya, sehingga dapat menimbulkan pertengkaran dengan sesama penghuni panti. Dimana pada penelitian ini ditunjukkan dengan masih terdapat ketidakcocokan antara masing-masing lansia dengan lansia lainnya karena pada pertanyaan tentang lansia sering berselisih faham dengan lansia lainnya menunjukkan banyak dari mereka yang sering terjadi pertengkaran karena tidak cocok dengan pendapat atau tindakan yang dilakukan oleh lansia lain., selain itu pada pertanyaan keingina lansia untuk pindah ke tempat lain masih mereka banyak mempunyai keinginan tersebut.

Berdasarkan hasil dari parameter adaptasi pribadi menunjukkan bahwa lansia yang kurang mampu melakukan adaptasi secara pribadi karena mereka merasa bahwa ketika mereka sudah ditempatkan di banyak lansia yang merasa belum mampu menyesuaikan dengan keadaan yang terjadi di panti werdha, lansia merasa risau dengan keadaan rambut yang memutih serta mereka merasa terganggu karena ketika memasuki usia lanjut kegiatan mereka lakukan berkurang sehingga lebih banyak menganggur hingga membuat mereka merasa bosan.

Bagi lansia yang masih belum mampu untuk melakukan adaptasi secara sosial disebabkan karena penyesuaian diri yang berat pada lansia yang bertempat tinggal di panti juga di pengaruhi oleh kurangnya aktivitas dan kegiatan keseharian mereka. Aktivitas dan kegiatan yang mereka lakukan sehari-hari hanya makan, tidur, sholat dan mandi, serta lansia merasa selalu merasa salah paham dengan teman yang lain dan mereka tidak dapat menyesuaikan dengan kehidupan yang dijalani oleh lansia di panti werdha

Berdasarkan alasan tinggal di panti werdha diperoleh data sebagian besar responden tingal di Panti Werdha Mojopahit karena keinginan sendiri sebanyak 23 responden $(62,2 \%)$. Berdasarkan hasil tabulasi silang antara alasan tinggal dipanti werdha dengan adaptasi sosial lansia menunjukkan data dari 22 responden yang mempunyai adaptasi sosial negatif terapat 12 responden $(52,2 \%)$ yang beralasan tinggal di panti karena keinginan sendiri dan 10 responden (45,5\%) tinggal dipanti karena adanya paksaan atau dorongan dari keluarga.

Banyaknya lansia tinggal di panti kebanyakn karena keinginan sendiri, dimana mereka merasa kesulitan untuk merasa optimis menjalani hidup jika harus tergantung dengan keluarga, dan mereka merisaukan keadaannya saat ini yang lebih banyak menganggur dan jarang beraktivitas serta rambut yang sudah memutih

\section{F. PENUTUP}

\section{Simpulan}

Adaptasi diri yang dilakukan lansia di Panti Werdha Mojopahit diperoleh data sebagian besar responden mempunyai adaptasi diri yang negatif sebanyak 22 responden $(59,5 \%)$.

\section{SARAN}

\section{a. Bagi Peneliti Berikutnya}

Untuk penelitian berikutnya diharapkan dapat melakukan pendekatan yang lebih baik lagi sehingga responden dapat lebih kooperatif, serta dapat ditambahkan teknik atau faktor lain yang dapat mempengaruhi adaptasi diri lansia agar dapat memperoleh hasil dengan lebih valid.

\section{b. Bagi profesi Kesehatan}

Pembinaan dan bimbingan agar lebih ditingkatkan lagi bagi tenaga kesehatan sehingga lansia dapat menjalani kehidupan sehari - hari dengan baik serta 
mempunyai mekanisme koping yang baik dalam menghadapi permasalahan terutama saat mereka harus berusaha menyesuaikan atau beradaptasi dengan lingkungan sekitarnya.

\section{c. Bagi Lansia}

Pemahaman tentang perubahan yang terjadi serta permasalahan yang akan terjadi pada kehidupan lansia supaya lebih ditingkatkan sehingga lansia dapat menerapkan atau mampu beradaptasi dengan kehidupan yang ada di sekitar mereka.

\section{DAFTAR PUSTAKA}

Ardi. (2013). Konsep Adaptasi. Tersedia di http://akperunipdu.blogspot.com/2008/05/stressdan-adaptasi.html diakses tanggal 5 Maret 2014

Arikunto, Suharsimi. (2006). Prosedur Penelitian : Suatu Pendekatan Praktis. Edisi revisi IV. Jakarta : Rineka Cipta

Keliat, B. A. (2009). Proses Keperawatan Jiwa. Jakarta: ECG

Maryam, Siti R. (2010). Mengenal Usia Lanjut dan Perawatannya. Jakarta : Salemba Medika' . (2008). Mengenal Usia Lanjut dan Perawatannya. Jakarta : Salemba Medika

Notoatmodjo. (2010). Metodologi Penelitian Kesehatan. Jakarta : Rineka Cipta

Nugroho. (2008). Keperawatan Gerontik. Edisi 2. Jakarta : EGC

Nursalam. (2013). Konsep dan Penerapan Metodologi Penelitian Ilmu Keperawatan. Jakarta : Salemba Medika

Prasetyo (2013). Well-Being Pada Lansia Yang Tinggal Di Panti Werdha Atas Dasar Keputusan Sendiri. Jurnal Fakultas Psikologi Universitas Katolik Widya Mandala Surabaya

Prasetyono. (2011). Penelitian Survey. Tersedia di http://galihdhephepjkra09.blogspot.com/2011/10/penelitian-survey.html diakses tanggal 05 Maret 2014

Pudjiastuti, S. (2003). Fisioterapi pada Lansia. Jakarta : EGC

Rosita (2012). Stressor Biologi lansia di Panti Werdha dan Lansia tinggal dengan keluarga. Jurnal. Antropologi FISIP Unair

Rufaida (2013). Hubungan antara Penyesuaian Diri dengan Depresi pada Pensiunan Pegawai. Jurnal Psikologi Universitas Sebelas Maret.

Saryono. (2010). Metodologi Penelitian Kebidanan. Yogyakarta : Nuha Medika 